\title{
Correspondência entre L.N. Tolstói e M.K. Gandhi
}

Belkiss J. Rabello

Tolstói manteve um interesse particular pela Índia, e foi um dos principais pensadores ocidentais a participar da elaboração da teoria da não-violência.

O indiano Tarak Nath Das (1884-1958) foi, em um primeiro momento, totalmente contrário às idéias sobre a não-violência. Sua ambição era libertar a Índia pela luta. Mais tarde, ele tornou-se amigo íntimo e também colaborador de Gandhi. Em 1908, T. Das, então editor de uma revista revolucionária chamada The Free Hindustan, escreve uma carta a Tolstói em que exprime sua opinião sobre as injustiças impostas pela Inglaterra, a mesma Inglaterra que, na mesma época, nutria-se de outros interesses e escravizava milhões de indianos. Segundo Tarak N. Das, apenas um movimento violento poderia libertar seu país. Tosltói responde-lhe, escrevendo aquela que ficaria conhecia como Carta a um Hindu, que se tornou um verdadeiro tratado de não-violência. Nela, Tolstói expõe suas teorias sobre a não-violência e sobre o amor. Nesta carta, Tolstói tentou igualmente alertar os indianos sobre a falta que cometiam ao renegar sua antiga sabedoria para abraçar o erro do Ocidente. Tolstói começa a carta citando um verso do livro sagrado dos Vedas, e termina-a citando Krishna.

Mahatma Gandhi, que já conhecia parte da obra de Tolstói, leu a Carta a um Hindu em uma tradução feita por Tchertkov. Depois 
de lê-la, Gandhi escreve a Tolstói, pedindo-lhe autorização para imprimi-la em 20.000 exemplares de seu jornal Indian Opinion, publicando-a em 1910, pouco tempo antes da morte de Tolstói. Além disso, Gandhi também o informa sobre o que ocorria na África do Sul, sobre seus pensamentos a respeito da resistência passiva, dentre outros assuntos. Depois da primeira carta escrita por Gandhi, datada de 1 de outubro de 1909, ambos mantêm uma correspondência densa, porém breve, interrompida definitivamente pela morte de Lev Tolstói. Conseguimos reunir quatro cartas de Gandhi para Tolstói: a primeira, escrita em 1 de outubro de 1909; a segunda, em 11 de novembro de 1909; a terceira, em 4 de abril de 1910 e, a última, em 15 de agosto de 1910. Além delas, três cartas de Tolstói endereçadas a Gandhi: a última, escrita em 7 de setembro de 1910; a penúltima, escrita em 8 de maio de 1910 e, a antepenúltima, em 7 de outubro de 1909.

“[...] Dormi mal. Passeei. Escrevi uma carta ao hindu e recebi uma simpática carta do hindu do Transvaal. A carta para o hindu está muito fraca".

“[...] Nada fiz de manhã. Escrevi uma carta para o hindu".

24 de setembro de 1909 .

L. N. Tolstói, Diários. 


\title{
Primeira carta escrita por Gandhi e endereçada a Tolstói
}

\author{
London, October 1, 1909
}

Sir,

I take the liberty of inviting your attention to what has been going on in the Transvaal (South Africa) for nearly three years.

There is in that Colony a British Indian population of nearly 13,000 . These Indians have, for several years, laboured under various legal disabilities. The prejudice against colour and in some respects against Asiatics is intense in that Colony. It is largely due, so far as Asiatics are concerned, to trade jealousy. The climax was reached three years ago, with a law which I and many others considered to be degrading and calculated to unman those to whom it was applicable. I felt that submission to a law of this nature was inconsistent with the spirit of true religion. I and some of my friends were and still are firm believers in the doctrine of non-resistance to evil. I had the privilege of studying your writings also, which left a deep impression on my mind. British Indians, before whom the position was fully explained, accepted the advice that we should not submit to the legislation, but that we should suffer imprisonment, or whatever other penalties the law may impose for its breach. The result has been that nearly one-half of the Indian population, that was unable to stand the head of the struggle, to suffer the hardships of imprisonment, have withdrawn from the Transvaal rather than submit to [the] law which they have considered degrading. Of the other half, nearly 2,500 have for conscience's sake allowed themselves to be imprisoned, some as many as five times. The imprisonments have varied from four days to six months, in the majority of cases with hard labour. Many have been financially ruined. At present there are over a hundred passive resisters in the Transvaal gaols. 
Some of these have been very poor men, earning their livelihood from day to day. The result has been that their wives and children have had to be supported out of public contributions, also largely raised from passive resisters. This has put a severe strain upon British Indians, but, in my opinion, they have risen to the occasion. The struggle still continues and one does not know when the end will come. This, however, some of us at least have seen most clearly, that passive resistance will and can succeed where brute force must fail. We also notice that, in so far as the struggle has been prolonged, it has been due largely to our weakness and, hence, to a belief having been engendered in the mind of the Government that we would not be able to stand continued suffering.

Together with a friend, I have come here to see the Imperial authorities and to place before them the position, with a view to seeking redress. Passive resisters have recognized that they should have nothing to do with pleading with the Government, but the deputation has come at the instance of the weaker members of the community, and it therefore represents their weakness rather than their strength.

But, in the course of my observations here, I have felt that if a general competition for an essay on the Ethics and Efficacy of Passive Resistance were invited, it would popularize the movement and make people think. A friend has raised the question of morality in connexion with the proposed competition. He thinks that such an invitation would be inconsistent with the true spirit of passive resistance and that it would amount to buying opinion. May I ask you to favour me with your opinion on the subject of morality? And if you consider that there is nothing wrong in inviting contributions, I would ask you also to give me the names of those whom I should specially approach to write upon the subject.

There is one thing more with reference to which I would trespass upon your time. A copy of your letter addressed to a Hindu on the present unrest in India has been placed in my hands by a friend. On the face of it, it appears to represent your views. It is the intention of my friend, at his own expense, to have 20.000 copies 
printed and distributed and to have it translated also. We have, however, not been able to secure the original, and we do not feel justified in printing it, unless we are sure of the accuracy of the copy and of the fact that it is your letter. I venture to enclose herewith a copy of the copy, and should esteem it a favour if you kindly let me know whether it is your letter, whether it is an accurate copy and whether you approve of its publication in the above manner. If you will add anything further to the letter, please do so. I would also venture to make a suggestion. In the concluding paragraph you seem to dissuade the reader from a belief in reincarnation. I do not know whether (if it is not impertinent on my part to mention this) you have specially studied the question. Reincarnation or transmigration is a cherished belief with millions in India, indeed, in China also. With many, one might almost say, it is a matter of experience, no longer a matter of academic acceptance. It explains reasonably the many mysteries of life. With some of the passive resisters who have gone through the gaols of the Transvaal, it has been their solace. My object in writing this is not to convince you of the truth of the doctrine, but to ask you if you will please remove the word "reincarnation" from the other things you have dissuaded your reader from. In the letter in question, you have quoted largely from Krishna and given reference to passages. I should thank you to give me the title of the book from which the quotations have made.

I have wearied you with this letter. I am aware that those who honour you and endeavour to follow you have no right to trespass upon your time, but it is rather their duty to refrain from giving you trouble, so far as possible, I have, however, who am an utter stranger to you, taken the liberty of addressing this communication in the interests of truth, and in order to have your advice on problems the solution of which you have your life-work.

With respects,

I remain, etc.,

M. K. Gandhi 
Belkiss J. Rabello. Correspondência entre L.N. Tolstói e M.K. Gandhi

\section{Tradução}

Londres, 1 de outubro de 1909

\section{Senhor,}

permita-me chamar a sua atenção para os acontecimentos que ocorrem no Transvaal (África do Sul) há, praticamente, três anos.

Nessa colônia há uma população de indianos britânicos constituída por cerca de 13.000 pessoas. Durante vários anos, esses indianos trabalharam em diversas condições ilegais. O preconceito contra a cor e, de certo modo, contra os asiáticos é intenso nessa colônia. No caso dos asiáticos, isso tem ocorrido, principalmente, devido à concorrência comercial. $\mathrm{O}$ ponto culminante deu-se há três anos com uma lei - considerada degradante por mim e por várias outras pessoas - especialmente criada para desumanizar aqueles a quem ela aplicava-se. Em minha opinião, a submissão a uma lei dessa natureza não condizia com o espírito da verdadeira religião. Alguns amigos e eu ainda acreditamos firmemente na doutrina da não-resistência ao mal. Tive o privilégio de estudar também os seus escritos, que deixaram profunda impressão em meu espírito. Os indianos britânicos, a quem a situação fora totalmente explicada, aceitaram o conselho de que não deveríamos nos submeter à legislação, mas que poderíamos ser presos ou sofrer quaisquer outras penalidades que a lei nos impusesse. O resultado foi que cerca da metade da população indiana, incapaz de resistir à luta, incapaz de suportar os rigores da prisão, preferiu deixar o Transvaal em vez de se submeter a essa lei, por ela considerada degradante. Da outra metade, cerca de 2.500 pessoas, deixou-se ser presa por uma questão de consciência, algumas delas até mesmo cinco vezes. As penas têm variado de quatro dias a seis meses e, na maior parte dos casos, com trabalhos forçados. Muitos ficaram financeiramente arruinados. Atualmente há mais de cem resistentes passivos nas prisões do Transvaal. Alguns deles são homens muito pobres, que ganham hoje para comer ama- 
nhã. O resultado é que suas mulheres e filhos tiveram de ser mantidos por contribuições públicas arrecadadas por resistentes passivos. Isso pesou muito sobre os indianos britânicos, mas, em minha opinião, eles corresponderam ao que lhes foi pedido. A luta ainda continua e não se sabe quando ela chegará ao fim. No entanto, ao menos alguns de nós perceberam com mais clareza que a resistência passiva vai e pode vencer lá, onde a força brutal certamente falhará. Nós percebemos igualmente que o fato de essa luta ter se prolongado deveu-se à nossa fraqueza e, portanto, à crença, por parte do governo, de que nós não seríamos capazes de resistir a sofrimentos constantes.

Vim a Londres, na companhia de um amigo, para ver as autoridades imperiais e para lhes expor a posição, na intenção de conseguir uma retratação. Os resistentes passivos reconhecem a inutilidade de se fazer solicitações junto ao governo, mas a delegação foi constituída pelos membros mais fracos da comunidade; portanto, ela representa mais a sua fraqueza do que a sua força.

No entanto, por aquilo que pude observar aqui, percebi que, se uma subscrição dos temas "ética" e "eficácia" da resistência passiva fosse criada, ela poderia popularizar o movimento e levar as pessoas a pensar. Um amigo levantou a questão sobre moralidade em relação a tal subscrição. Ele acredita que um convite como esse contrariaria o verdadeiro espírito de resistência passiva, e poderia levar a crer que seu objetivo é condicionar a opinião pública. Eu gostaria de lhe pedir o favor de me agraciar com a sua opinião sobre esse assunto. E, caso o senhor considere que nada há de errado em fazermos uma subscrição, eu gostaria também de lhe pedir nomes de pessoas a quem eu pudesse me endereçar especialmente para tratar desse assunto.

Há ainda uma coisa a mais em relação a esse mesmo assunto que me faz abusar de seu tempo. Uma cópia de sua carta endereçada a um hindu, sobre a atual agitação na Índia, foi-me entregue por um amigo. À primeira vista, ela parece-me exprimir suas convicções. Meu amigo tem a intenção de, com seus próprios meios, traduzi-la, 
imprimi-la em 20.000 cópias, e distribuí-la. Nós, no entanto, não pudemos obter o original, e não julgamos correto imprimi-la sem estarmos seguros da exatidão do texto; seria grande gentileza de sua parte se o senhor pudesse me dizer se a carta é sua, se a cópia é exata e se o senhor aprova a sua publicação nos termos que lhe expus. Se o senhor desejar acrescentar qualquer coisa que seja à carta, faça-o, por favor. Eu ainda gostaria de me permitir fazer uma sugestão. Ao concluir, o senhor parece dissuadir o leitor da crença na reencarnação. Não sei (caso não seja impertinência minha mencionar isso) se o senhor teve a oportunidade de ter estudado especialmente essa questão. Reencarnação, ou transmigração, é uma crença bastante cara a milhões de pessoas tanto na Índia como também na China. Creio que podemos dizer que, para muitos, trata-se de uma questão de experiência, e não mais uma questão de aceitação acadêmica. A reencarnação explica, de maneira razoável, os vários mistérios da vida. Para muitos resistentes passivos que estiveram nas cadeias do Transvaal, ela foi o seu conforto. Meu objetivo, ao lhe escrever sobre isso, não é o de convencê-lo da verdade da doutrina, mas sim o de lhe perguntar se o senhor poderia suprimir a palavra "reencarnação" das outras idéias das quais o senhor dissuadiu o leitor. Na carta em questão, o senhor citou Krishna muitíssimas vezes e remeteu o leitor a certas passagens. Eu ficar-lhe-ia grato se o senhor fornecesse-me o título do livro do qual as citações foram extraídas.

Importunei-o com esta carta. Tenho a consciência de que aqueles que lhe honram e empenham-se em segui-lo não têm o direito de abusar de seu tempo, ao contrário, eles têm o dever de, sempre que possível, evitar importuná-lo; no entanto, eu, que sou um estranho para o senhor, tomei a liberdade de lhe endereçar esta mensagem no interesse da verdade, e com a finalidade de receber o seu conselho quanto a problemas cuja solução tem sido o objetivo do trabalho de toda a sua vida.

Com respeito,

Seu sempre...

K.M. Gandhi 


\section{Resposta de Tolstói a Gandhi}

Сейчас получия ваше в вышей степени и интересное и доставившее мне большую радость письмо. Помогай Бог нашим дорогим братьям и сотрудникам в Трансваале. Та же борьба мягкого против жесткого, смирения и дюбви против гордости и насидия с каждым годом все более и более проявдяется и у нас, в особенности в одном из самых резких столкновений закона религиозного с законом мирским в отказах от военной службы. Отказы становятся все чаще и чаще.

Письмо к индус3 писано мною. Перевод очень хорош. Заглавие книги о Кришне вам будет выслано из Москвы.

Слово reincarnation мне бы не хотелось исключать, потому что, по моему мнению, вера в reincarnation никогда не может быть так тверда, как вера в неумираемость души и в справедливость и дюбовь Бога. Впрочем, делайте, как хотите. Переведу на индусский язык моего письма и распространению его могу только радоваться.

Думаю, что competition, т.е. денежное поощрение, в деле религиозном неуместно. Если я могу служить чем вашему изданию, то буду очень рад.

Братски приветствую вас и радуюсь общению с вами.

7 окт. 1909 


\title{
Tradução
}

\author{
Conde Lev Tolstói \\ Iásnaia Poliana, Rússia
}

\section{7 de outubro de 1909}

Acabei de receber sua interessantíssima carta que me proporcionou grande alegria. Que Deus ajude nossos queridos irmãos e colaboradores no Transvaal. Todos os anos vemos, cada vez mais, crescer aqui a manifestação desta mesma luta: da doçura contra a brutalidade, da humildade e do amor contra a arrogância e a violência; luta que cresce particularmente na forma de um dos mais intensos conflitos entre a lei religiosa e a lei civil: o serviço militar. Tais recusas tornam-se mais e mais freqüentes.

A “Carta a um Hindu” foi escrita por mim. A tradução está muito boa. O título do livro sobre Krishna ser-lhe-á enviado de Moscou.

Prefiro não excluir o termo reincarnation ${ }^{1}$ porque, em minha opinião, a fé na reincarnation ${ }^{2}$ nunca poderá ser tão firme quanto a fé na imortalidade da alma e na justiça e amor de Deus. No entanto, faça como achar melhor. A tradução de minha carta para a língua indiana, bem como sua difusão, nada mais me trarão além de alegria.

Creio que competition ${ }^{3}$, ou seja, remuneração em dinheiro, é algo descabido quando se trata de uma causa religiosa. Ficarei muito satisfeito se puder colaborar com a sua publicação.

Saúdo-o fraternalmente e fico feliz em manter contato com o senhor. 


\section{Segunda carta escrita por Gandhi e endereçada a Tolstói}

London, November 10, 1909

Dear Sir,

I beg to tender my thanks for your registered letter in connection with the letter addressed to a Hindu, and with the matters that I dealt with in my letter to you.

Having heard about your failing health I refrained, in order to save you the trouble, from sending an acknowledgment, knowing that a written expression of my thanks was a superfluous formality; but Mr. Aylmer Maude, whom I have now been able to meet reassured me that you were keeping very good health indeed and that unfailingly and regularly you attended to your correspondence every morning. It was a very gladsome news to me, and it encourages me to write to you further about matters which are, I know, of the greatest importance according to your teaching.

I beg to send you herewith a copy of a book written by a friend - an Englishman, who is at present in South Africa, in connection with my life, in so far as it has a bearing on the struggle with which I am so connected, and to which my life is dedicated. As I am very anxious to engage your active interest and sympathy, I thought that it would not be considered by you as out of the way for me to send you the book.

In my opinion, this struggle of the Indians in the Transvaal is the greatest of modern times, inasmuch as it has been idealized both as to the goal as also the methods adopted to reach the goal. I am not aware of a struggle in which the participators are not to derive any personal advantage at the end of it, and in which 50 per cent of the persons affected have not undergone great suffering and trial for 
the sake of a principle. It has not been possible for me to advertise the struggle as much as I should like. You command, possibly, the widest public today. If you are satisfied as to the facts you will find set forth in Mr. Doke's book, and if you consider that the conclusions I have arrived at are justified by the facts, may I ask you to use your influence in any manner you think fit to popularize the movement? If it succeeds, it will be not only a triumph of religion, love and truth over irreligion, hatred and falsehood, but it is highly likely to serve as an example to the millions in India and to people in other parts of the world, who may be down-trodden and will certainly go a great way towards breaking up the party of violence, at least in India. If we hold out to the end, as I think you would, I entertain not the slightest doubt as to its ultimate success; and your encouragement in the way suggested by you can only strengthen us in our resolve.

The negotiations that are going on for a settlement of the question have practically fallen through, and together with my colleague I return to South Africa this week, and invite imprisonment. I may add that my son has happily joined me in the struggle and is now undergoing imprisonment with hard labour for six months. This is his fourth imprisonment in the course of the struggle.

If you would be so good as to reply to this letter, may I ask you to address your reply to me at Johannesburg, S.A., Box 6522.

Hoping that this will find you in good health.

I remain, etc.

Obs.: Doente, Tolstói jamais respondeu a essa carta. 


\section{Tradução}

Londres, 10 de novembro de 1909

Prezado senhor,

peço-lhe que aceite meus agradecimentos por sua correspondência registrada, relativa à carta endereçada a um hindu, bem como às questões tratadas na carta que enderecei ao senhor.

Eu soube de sua debilitada saúde e, para lhe evitar o incômodo de uma resposta, ia me limitar a acusar o recebimento, sabendo que uma carta escrita, expressando os meus agradecimentos, não passaria de simples formalidade supérflua; mas Aylmer Maude, com quem pude me encontrar, assegurou-me que o senhor estava em boa saúde e que, regular e infalivelmente, cuidava, todas as manhãs, de sua correspondência. Foi uma grata notícia para mim, e ela encoraja-me a lhe escrever mais detalhadamente sobre problemas que são, eu reconheço, da maior importância em função de seus ensinamentos.

Peço-lhe que aceite o exemplar adjunto de um livro escrito por um amigo, um inglês que, atualmente, encontra-se na África do Sul. Este livro está relacionado à minha vida, na medida em que ele apóia a luta na qual estou tão envolvido e a qual dediquei minha vida inteira. Como estou muito ansioso para despertar seu interesse e simpatia, creio que o senhor não consideraria um gesto inoportuno de minha parte enviar-lhe este livro.

Em minha opinião, essa luta dos indianos no Transvaal é a maior dos tempos modernos, visto que ela foi idealizada visando-se tanto o objetivo como os métodos empregados para alcançá-lo. Não conheço luta em que, ao final, os participantes não tirem algum proveito pessoal, e em que $50 \%$ das pessoas nela envolvidas não tenham passado por grandes sofrimentos e provações em nome de algum princípio. Não me foi possível divulgar essa luta tanto quan- 
to eu gostaria. Hoje o senhor atinge, possivelmente, o mais numeroso público. Se o senhor ficar satisfeito com os fatos tratados pelo Sr. Doke em seu livro, e se o senhor considerar que as conclusões as quais cheguei são justificadas pelos fatos, posso lhe pedir que use de sua influência da maneira, seja ela qual for, que o senhor julgar adequada para popularizar o movimento? Se obtivermos sucesso, esse movimento não será apenas o triunfo da religião, do amor e da verdade sobre a falta de religião, o ódio e a falsidade, mas é muito provável que [essa vitória] sirva de exemplo a milhões [de pessoas] que possam vir a ser espezinhadas na Índia e em outras partes do mundo. Certamente ela será um bom meio para quebrar o partido da violência, ao menos na Índia. Se nós resistirmos até o fim, e tenho a certeza de que o senhor irá fazê-lo, não tenho a menor dúvida a respeito do sucesso final; e o seu encorajamento, na forma que o senhor julgar melhor, apenas poderá reforçar a nossa situação.

As negociações que estavam em andamento sobre a regulamentação desta questão praticamente fracassaram e, na companhia de um amigo, volto para a África do Sul nesta semana, expondo-me à possibilidade de ser preso. Acrescento ainda que meu filho juntou-se calorosamente a mim nesta luta e agora está preso, cumprindo pena de seis meses de trabalhos forçados. Esta foi a quarta vez, no decorrer de nossa luta, que ele foi preso.

Se o senhor tiver a bondade de responder a esta carta, pedirlhe-ei endereçar a sua resposta para Johannesburg, S.A., Box 6522

Na esperança de que esta carta encontre-o em boa saúde,

Seu obediente devoto,

M.K. Gandhi. 


\title{
Terceira carta escrita por Gandhi e enviada a Tolstói
}

\author{
Johannesburg, \\ Transvaal, South Africa
}

April 4, 1910

\section{Dear Sir,}

you will recollect my having carried on correspondence with you whilst I was temporarily in London. As a humble follower of yours, I send you herewith a booklet which I have written. It is my own translation of a Gujarati writing. Curiously enough, the original writing has been confiscated by the Government of India. I, therefore, hastened the above publication of the translation. I am most anxious not to worry you, but, if your health permits it and if you can find the time to go through the booklet, needless to say I shall value very highly your criticism of the writing. I am sending also a few copies of your Letter to a Hindou, which you authorized me to publish. It has been translated in one of the Indian languages also.

I am,

Your obedient servant, 


\section{Tradução}

Johannesburg,

Transvaal, África do Sul,

4 de abril de 1910

Prezado senhor,

o senhor estará lembrado de que eu mantive correspondência com o senhor durante minha breve estadia em Londres. É como humilde discípulo seu que eu lhe envio junto com esta carta um pequeno livro que escrevi. Trata-se de uma tradução que fiz do original, escrito em gujarati. Curiosamente, o texto original foi confiscado pelo governo indiano. Por esse motivo, apressei-me em publicar esta tradução. Temo incomodá-lo, mas, se a sua saúde permitir, e se o senhor tiver tempo para folhear o livro, desnecessário dizer que eu apreciaria muitíssimo suas críticas sobre o texto. Envio-lhe também algumas cópias de sua Carta a um Hindu, que o senhor autorizou-me a publicar. Ela também foi traduzida para uma das línguas da Índia.

Seu humilde servo,

M.K. Gandhi. 


\section{Resposta de Tolstói a Gandhi}

Yasnaya Polyana

8 th May 1910

Dear friend,

I have just received your letter and your book, The Indian Home Rule.

I read your book with great interest because I think the question you treat in it: the passive resistance - is a question of the greatest importance, not only for India but for the whole humanity.

I could not find your former letters, but came across your biography by J. Doss, which too interested me much and gave me the possibility to know and understand your better.

I am not quite well at present and therefore abstain from writing to you all what I have to say about your book and all your work, which I appreciate very much, but I will do it as soon, as I will feel better.

Your friend and brother

Leo Tolstoy 
Belkiss J. Rabello. Correspondência entre L.N. Tolstói e M.K. Gandhi

\section{Tradução}

Iásnaia Poliana,

8 de maio de 1910

Prezado amigo,

acabei de receber sua carta e seu livro The Indian Home Rule.

Li seu livro com grande interesse porque penso que a questão nele tratada, a resistência passiva, é questão da maior importância não apenas para a Índia, mas para toda a humanidade.

Não pude encontrar suas cartas antigas, mas percorri sua biografia, escrita por J. Doss, que também me interessou muito, e possibilitou-me conhecê-lo e compreendê-lo melhor.

Não me sinto muito bem no momento e, por conseguinte, [também] privado de lhe escrever tudo aquilo que tenho a dizer sobre seu livro e sobre todo o seu trabalho, que muito apreciei; mas farei isso tão logo me sinta melhor.

Seu amigo e irmão,

Lev Tolstói 


\section{Quarta carta escrita por Gandhi e endereçada a Tolstói}

Johannesburg,

August 15, 1910

Dear Sir,

I am much obliged to you for your encouraging and cordial letter of the $8^{\text {th }}$ May last. I very much value your general approval of my booklet, Indian Home Rule. And, if you have the time, I shall look forward to your detailed criticism of the work which you have been so good as to promise in your letter.

Mr. Kallenbach has written to you about Tolstoy Farm. Mr. Kallenbach and I have been friends for many years. I may state that he has gone through most of the experiences that you have so graphically described in your work, My Confessions. No writings have so deeply touched Mr. Kallenbach as yours; and, as a spur to further effort in living up to the ideals held before the world by you, he has taken the liberty, after consultation with me, of naming his farm after you.

Of his generous action giving the use of the farm for passive resisters, the number of Indian Opinion I am sending herewith will give you full information.

I should not have burdened you with these details but for the fact of your taking a personal interest in the passive resistance struggle that is going on in the Transvaal.

I remain,

Your faithful servant,

M. K. Gandhi 


\section{Tradução}

Johannesburg,

15 de agosto de 1910

Prezado senhor,

agradeço-lhe profundamente por sua encorajadora e cordial carta de 8 de maio passado. Aprecio muitíssimo a sua aprovação geral de meu pequeno livro Indian Home Rule. E, se o senhor dispuser de tempo, aguardarei suas críticas detalhadas sobre o trabalho, generosamente prometidas em sua carta.

O senhor Kallenbach escreveu-lhe sobre a Fazenda Tolstói. O senhor Kallenbach e eu somos amigos há muitos anos. Posso lhe afirmar que ele vivenciou a maior parte das experiências que o senhor descreveu de maneira tão pitoresca em seu trabalho Minhas Confissões. Nenhum outro texto tocou tão profundamente o senhor Kallenbach como o seu; e, como um estímulo para um ulterior esforço para viver de acordo com o ideal apresentado ao mundo pelo senhor, ele tomou a liberdade, depois de se consultar comigo, de dar seu nome à fazenda dele.

De seu ato generoso de permitir o uso da fazenda aos resistentes passivos pode ser lido no número de Indian Opinion que estou lhe enviando em adjunto, e no qual o senhor encontrará informações mais completas.

Eu não o teria sobrecarregado com esses detalhes se não fosse o interesse pessoal que o senhor tem manifestado pela luta pela resistência passiva que se desenrola agora no Transvaal.

Permaneço

Seu humilde servo,

M.K. Gandhi 


\section{Resposta de Tolstói a Gandhi}

Получил ваш журнал Indian Opinion и был рад узнать все то, что там пишется о непротивляющихся. И захотелось сказать вам те мысли, которые вызвали во мне это чтение.

Чем дольше я живу, и в особенности теперь, когда живо чувствую близость смерти, мне хочется сказать другим то, что я так особенно живо чувствую и что, по моему мнению, имеет огромную важность, а именно о том, что называется непротивлением, но что в сущности есть не что иное, как учение любви, не извращенное ложными толкованиями. То, что дюбовь, т.е. стремление душ человеческих к единению, и вытекающая из этого стремления деятельность есть высший и единственный закон жизни человеческой, это в глубине души чувствует и знает каждый человек (как это мы яснее видим на детях), знает, пока он не запутан ложными учениями мира. Закон этот был провозглашен всеми, как индийскими, так и китайскими и еврейскими, греческими, римскими мудрецами мира. Думаю, что он яснее всего был высказан Христом, который даже прямо сказал, что в этом одном весь закон и пророки. Но мало этого, предвидя то извращение, которому подвергается и может подвергнуться этот закон, он прямо указал на ту опасность извращения его, которая свойственна людям, живущим мирскими интересами, а именно ту, чтобы разрешать себе защиту этих интересов силою, т.е., как он сказал, ударами отвечать на удары, силою отнимать назад, присвоенные предметы и т.п. и т.п. Он знает, как не может не знать этого каждый разумный человек, что употребление насилия несовместимо с любовью как с 
основным законом жизни, что, как скоро допускается насилие, в каких бы то ни было случаях, признается недостаточность закона дюбви и потому отрицается сам закон. Вся христианская, столь блестящая по внешности, цивилизация выросла на этом явном и странном, иногда сознательном, большей частью бессознательном, недоразумении и противоречии.

В сущности, как скоро было допущено противление при любви, так уже не было и не могло быть дюбви как закона жизни, а не было закона жизни, кроме насилия, т.е. власти сильнейшего. Так 19 веков жило христианское человечество. Правда, во все времена люди руководствовадись одним насилием в устройстве своей жизни. Разница жизни христианских народов от всех других только в том, что в христианском мире закон любви был выражен так ясно и определенно, как он не был выражен ни в каком другом религиозном учении, и что люди христианского мира торжественно приняли этот закон и вместе с тем разрешили себе насилие и на насилии построили свою жизнь. И потому вся жизнь христианских народов есть сплошное противоречие между тем, что они исповедуют, и тем, на чем строят свою жизнь: противоречие между дюбовью, признанной законом жизни, и насилием, признаваемым даже необходимостью в разных видах, как власть правителей, суды и войска, признаваемым и восхваляемым. Противоречие этого все росло вместе с развитием пюдей христианского мира и в последнее время дошио до последней степени. Вопрос теперь стоит очевидно так: одно из двух: или признать то, что мы не признаем никакого религиозно-нравственного учения и руководствуемся в устройстве нашей жизни одной 
властью сильного, или то, что все наши, насилием собираемые, подати, судебные и подицейские учреждения и, главное, войска должны быть уничтожены.

Нынче весной на экзамене закона божия одного из женских институтов Москвы законо-учитель, а потом и присутствовавший архиерей спрашивали девиц о заповедях и особенно о шестой. На правильный ответ о заповеди архиерей обыкновенно задавал еще вопрос: всегда ли во всех случаях запрещается законом божиим убийство, и несчастные, развращенные своими наставниками девицы должны были отвечать и отвечади, что не всегда, что убийство разрешено на войне и при казнях преступников. Однако, когда одной из несчастных девиц этих (то, что я рассказываю, не выдумка, а факт, переданный мне очевидцем) на ее ответ был задан тот же обычный вопрос: всегда ди греховно убийство? она, волнуясь и краснея, решительно ответила, что всегда, а на все обычные софизмы архиерея отвечала решительным убеждением, что убийство запрещено всегда и что убийство запрещено и в Ветхом завете и запрещено Христом не тодько убийство, но и всякое зло против брата. И, несмотря на все свое величие и искусство красноречия, архиерей замолчал, и девушка ушла победительницей.

Да, мы можем толковать в наших газетах об успехах авиации, о сложных дипломатических сношениях, о разных клубах, открытиях, союзах всякого рода, так называемых художественных произведениях и замалчивать то, что сказала эта девица; но замалчивать этого нельзя, потому что это чувствует более или менее смутно, но чувствует всякий человек христианского мира. Социализм, коммунизм, анархизм, армия 
Belkiss J. Rabello. Correspondência entre L.N. Tolstói e M.K. Gandhi

спасения, увеличивающаяся преступность, безработность населения, увеличивающаяся безумная роскошь богатых и нищета бедных, страшно увеличивающееся число самоубийств, все это признаки того внутреннего противоречия, которое доджно и не может не быть разрешено. И. Разумеется разрешено в смысле признания закона любви и отрицания всякого насилия. И потому ваша деятельность в Трансваале, как нам кажется на конце света, есть дело самое центральное, самое важное из всех дел, какие делаются теперь в мире и участие в котором неизбежно примут не только народы христианского, но всякого мира. Думаю, что вам приятно будет узнать, что у нас в России тоже деятельность эта быстро развивается в форме отказов от военной службы, которых становится с каждым годом все бодьше и бодьше. Как ни ничтожно количество и ваших дюдей, непротивляющихся, и у нас в России число отказывающихся, и те и другие могут смедо сказать, что с ними Бог. А Бог могущественнее людей.

В признании христианства, хотя бы и в той извращенной форме, в которой оно исповедуется среди христианских народов, и в признании вмести с этим необходимости войск и вооружения для убийства в самых огромных размерах на войнах, заключается такое явное, вопиющее противоречие, что оно неизбежно должно рано или поздно, вероятно очень рано, обнаружиться и уничтожить или признание христианской религии, которая необходима для поддержания власти, или существование войска и всякого поддерживаемого им насидия, которое для власти не менее необходимо. Противоречие это 


\begin{abstract}
чувствуется всеми правительствами, как вашим британским, так нашим русским, и из естественного чувства самосохранения преследуется этими правительствами более энергично, как это мы видим в России и как это видно из статей вашего журнала, чем всякая другая антиправительственная деятельность. Правительства знают, в чем их главная опасность, и зорко стерегут в этом вопросе уже не только свои интересы, но вопрос быть или не быть.
\end{abstract}

C совершенным уважением Leo Tolstoy. 7 сент. 1910 г. Кочеты 


\section{Tradução}

Kotchety,

7 de setembro de 1910 .

Recebi sua revista Indian Opinion e fiquei feliz em conhecer o que nela escrevem a respeito dos adeptos da teoria da não-violência. Gostaria de expressar os pensamentos que essa leitura despertou em mim.

Quanto mais tempo eu vivo - e principalmente agora que sinto com clareza a aproximação da morte - mais forte torna-se a necessidade de transmitir a outras pessoas sobretudo aquilo que sinto tão profundamente e que, em minha opinião, é de enorme importância, a saber: o que chamam de não-violência nada mais é, em sua essência, do que a doutrina do amor, livre de falsas interpretações. Ora, o amor, ou seja, a aspiração das almas humanas à união, bem como a atividade que provém dessa aspiração, representam a única e suprema lei da vida humana, e cada pessoa sabe e sente isso no fundo de sua alma (esse fato torna-se mais evidente em crianças); todo ser humano tem conhecimento disso até o momento em que não se confunde com falsos ensinamentos do mundo. Esta lei foi apregoada por todos os sábios da terra: tanto por hindus como por chineses, hebreus, gregos e romanos. Acredito ter sido ela muito claramente expressa por Cristo: ele chegou a dizer exatamente que esta única lei encerra toda a Lei e, inclusive, os profetas. Além disso, Ele previu o aviltamento a que esta Lei está exposta, e apontou claramente o perigo de tal aviltamento, comum aos homens que vivem precisamente por interesses mundanos, isto é, apontou o perigo de os seres humanos permitirem a si próprios defender tais interesses pela força, ou, tal como Ele disse, responder com golpe ao golpe, usar de força para recuperar aquilo que lhe foi tomado, etc. Ele sabia aquilo que qualquer ser racional não pode deixar de saber, que o emprego da violência não é compatível com o amor, lei básica da 
vida. Enquanto a violência é praticada, sejam quais forem as circunstâncias, admite-se a insuficiência da lei do amor e, por conseguinte, essa mesma lei é negada. Toda a civilização cristã, tão brilhante em sua aparência, desenvolveu-se sobre uma contradição e sobre equívocos demasiadamente óbvios e estranhos, algumas vezes conscientes, mas, na maioria dos casos, inconscientes.

Em resumo, quando a resistência foi incorporada ao amor, já não havia - e tampouco poderia haver - amor enquanto lei da vida e, não havendo a lei da vida, nada poderia existir senão a violência, ou seja, o poder do mais forte. A humanidade cristã viveu dessa maneira durante dezenove séculos. É verdade que, durante todos os tempos os homens guiaram-se unicamente pela violência na organização de suas vidas. A diferença entre os povos cristãos e todos os outros reside apenas nisto: no mundo cristão, a lei do amor foi expressa com clareza total e com precisão, como nunca antes havia sido expressa em qualquer outro ensinamento religioso, e os homens desse mundo cristão aceitaram solenemente tal lei e, ao mesmo tempo, permitiram a si mesmos o uso da violência, construindo nela as suas vidas. E, por isso, toda a vida dos povos cristãos está em contradição entre aquilo que eles pregam e entre a base de suas vidas: contradição entre o amor, considerado a lei da vida, e a violência, considerada até mesmo como imprescindível em todas as suas diferentes formas, tais como o poder dos governantes, dos tribunais, dos exércitos, reconhecidos e louvados. Essa contradição continuou crescendo paralelamente ao desenvolvimento do mundo dos cristãos e, ultimamente, atingiu o mais alto grau. Hoje, a questão é, evidentemente, uma das seguintes: ou reconhecer que nós não aceitamos qualquer ensinamento moral-religioso, e que nos norteamos, na construção de nossas vidas, unicamente pelo poder do forte, ou que todos os nossos impostos, violentamente arrecadados, e que todos os órgãos judiciais e policiais e, em princípio, os exércitos, devem ser abolidos.

Agora, na primavera, durante o exame de catecismo em um dos institutos femininos de Moscou, um professor de catecismo e, 
em seguida, um bispo ali presente interrogaram as moças sobre os Mandamentos, especialmente sobre o sexto. Depois das respostas corretas sobre esse mesmo assunto, o bispo costumava perguntar se o assassinato era sempre proibido pela lei de Deus, não importando as circunstâncias. E, corrompidas por seus mestres, as infelizes moças deviam responder - e respondiam - que nem sempre, que o assassinato era permitido na guerra e para castigar os criminosos. No entanto, após responder, a uma daquelas infelizes moças (e o que relato aqui não é mentira, mas um fato que me foi transmitido por uma testemunha) foi feita a habitual pergunta: o assassinato é sempre um pecado? Emocionada e ruborizada, ela respondeu com firme convicção que "sempre". E, a todos os costumeiros sofismas do bispo, ela respondia com convicção firme que o assassinato é sempre proibido, e que ele havia sido proibido já no Velho Testamento, e também por Cristo, e que, não somente o assassinato, mas todo tipo de mal contra o próximo. E, apesar de toda a sua grandeza e eloqüência, o bispo calou-se, e a moça saiu vitoriosa.

Sim, nós podemos falar em nossos jornais sobre os êxitos da aviação, sobre relações diplomáticas complexas, sobre os diversos clubes, as descobertas, as mais variadas alianças, bem como sobre as assim chamadas obras artísticas, e podemos calar sobre o que aquela moça disse. Calar, no entanto, é impossível; qualquer homem do mundo cristão sente isso de maneira vaga, mas o sente. $\mathrm{O}$ socialismo, o comunismo, o anarquismo, o Exército da Salvação, o crescimento da criminalidade, o desemprego, o aumento do luxo excessivo dos ricos e a miséria dos pobres, bem como o espantoso crescimento do número de suicídios, tudo isso são sinais de contradição interna, que deve, e não pode deixar de ser resolvida. E, sem dúvida, resolvida no sentido da aceitação da lei do amor e da negação de qualquer violência. É por isso que sua atividade no Transvaal, lugar que nos parece localizado nos confins da terra, é um trabalho central, o mais importante dentre todos os já realizados ultimamente no mundo, em que participarão, certamente não apenas os povos cristãos, mas povos do mundo todo. Acredito, ser-lhe-á agradável 
saber que entre nós, na Rússia, essa atividade também se desenvolve rapidamente sob a forma de recusa ao serviço militar, que aumenta mais e mais a cada ano. Por menor que seja o número dos adeptos da teoria da não-violência, também aqui, na Rússia, poucos são os que ainda recusam o serviço militar e, tanto estes como aqueles podem, corajosamente, dizer que Deus está com eles. E Deus é mais poderoso do que os homens.

$\mathrm{Na}$ aceitação do cristianismo, apesar da forma deturpada pela qual ele é praticado entre os povos cristãos, e na aceitação, ao mesmo tempo, da necessidade dos exércitos e armamento para assassinatos em larga escala nas guerras, existe uma contradição tão óbvia e tão gritante que deve, inevitavelmente, mais cedo ou mais tarde (parece que mais cedo), ser verificada. Essa contradição deve abolir a aceitação de qualquer religião cristã - necessária para apoiar o poder - ou abolir a existência do exército e da violência apoiada pelo exército, ambos igualmente necessários ao poder. Essa contradição é percebida por todos os governos que são guiados pelo instinto de sobrevivência, tanto pelo seu, o britânico, como pelo nosso, o russo. Esses governos perseguem mais energeticamente a contradição do que qualquer outra atividade antigovernamental: observamos isso na Rússia e vemos isso nos artigos da sua revista. Os governos sabem em que reside o maior perigo para eles: em cuidar atentamente nessa questão não apenas de seus próprios interesses, mas também da questão de sua própria existência.

Com toda a minha estima,

Lev Tolstói

Traduções: Belkiss Rabello

Revisão da tradução do russo: Elena Vássina 
